\title{
The Effect of International Currency Crises on the Balance of Payments: Evidence From Jordan
}

\author{
Tamer Rawashdeh ${ }^{1}$, Mahmoud Al-Rdaydeh ${ }^{2}$ \& Basem Hamouri $^{3}$ \\ ${ }^{1}$ Department of Finance and Banking, Economics and Administrative Sciences Faculty, Yarmouk University, Jordan \\ 2 Departement of Business Adminstartion, Ibn Rushd College for Management Sciences, Abha, Saudi Arabia \\ ${ }^{3}$ Department of Finance, Business College, Al Balqa applied University, Jordan \\ Correspondence: Mahmoud Al-Rdaydeh, Ibn Rushd College for Management Sciences, King Abdul Aziz Road, Abha \\ 61411, Saudi Arabia. E-mail: mahmouda27@gmail.com
}

Received: July 11, 2020

doi:10.5430/ijfr.v11n5p275
Accepted: August 19, 2020

Online Published: October 4, 2020

URL: https://doi.org/10.5430/ijfr.v11n5p275

\begin{abstract}
The effect of the international currency crises on the Jordanian balance of payments (BoP) between Q1-2000 and Q4-2017 was investigated in this paper. The currency crises are represented by the various exchange rates (ER) for the Japanese Yen, United States (US) Dollar, Euro Member Countries, China Renminbi, and the United Kingdom (UK) Pound with the Jordanian Dinar. In approximating the potential short-run and long-run associations among the different ER variations and the BoP, the ARDL bounds testing technique was employed. The empirical findings revealed that variation in the ER rate for EUR/JOD had a positive significant impact on the BOP for the short-run and long-run relation, whereas, opposingly, for the JPY/JOD, it had a negative significant impact on the BoP in the short-run and long-run relations. For other currencies, the results varied. Therefore, to reduce the effect of currency fluctuations and resultant crises on the BoP, over-reliance on the promotion and importation of goods and domestic export products should be avoided. As such, in the context of the Jordanian economy, the country needs to diversify. Accordingly, this can only be achieved if the economy is expanded along with advancing and developing entrepreneurial innovation supported by fiscal disciplines.
\end{abstract}

Keywords: international currency crisis, balance of payments, ARDL, Jordan

\section{Introduction}

Balance of payment (BoP) has attracted significant attention globally, specifically in economic and finance domains (Batool, Memood, \& Jadoon, 2015; Gouvea \& Lima, 2013; Hutchison \& Noy, 2002; Kalayci, 2019; Kandil, 2009; R. S. Ribeiro, McCombie, \& Lima, 2016; R. S. M. Ribeiro, 2019). Moreover, the concept surrounding BoP is of major importance in reversing the economic situations in many countries, in monitoring and acknowledging the economic strength of a country, its impact on global economic variables, and demonstrating the association with other countries through the movement of economic and financial exchange and other services. From a global perspective, managing BoP is extremely important since it is influenced by external and internal economic factors (Kandil \& Greene, 2002).

Notably, developing countries mainly suffer or are disadvantaged in many respects due to the openness of their economies to the economies of other developed countries, making them more vulnerable or exposed to international economic variations or fluctuations. As such, they are more exposed to external crises, which adversely affects the extent of stability from a local perspective (Alawin \& Oqaily, 2017; Hamouri, et al., 2018). Moreover, the impact brought about through the external changes of a country is also affected by its BoP, which, in turn, is also affected by developing countries in addition to external indebtedness, foreign aid, and grants, including ERs, changes in terms of trade, slowing growth rates, real international INTs, and internal factors including fiscal deficit and indebtedness.

Jordan is a relatively small country having a low impact economy relative to the global economy and is open to international trade, which makes it vulnerable to external factors affecting the BoP (Alawin \& Oqaily, 2017; Al-Rdaydeh, et al., 2018). The most important of these factors is the international currency crisis, the increase of relations between countries, the large volume of international trade, and resulting international payments. As such, this necessitates the need for a mechanism to compare in at least two currencies in order to determine the price of the 
transaction or deal, known as the ER, which is important to each country. Prominent currencies that have frequently been employed in conducting international transactions include the (US) dollar, the euro, and (UK) pound sterling. Given the changes associated with the movement of capital between countries and forms of settling, the so-called international currency crisis and currency war between countries with major economies evolved.

The term 'currency crisis' can be defined as the depreciation of a particular currency, foreign exchange crisis, or BoP crisis, which are all familiar terms used nowadays to describe such a crisis. This form of crisis associated with international currencies is harmful to the economy, which extends to neighboring countries, including countries with economic relations with the same country. The currency crisis has accordingly impacted numerous countries globally, consequently impacting adversely on these countries and neighboring countries. For example, Mexico, Argentina, Asia, Russia, and Turkey have all experienced a currency crisis. In another example, 15 countries exposed to currency crises were able to supply foreign currencies acceptable to the country they dealt with. However, the more these conditions deteriorate, the more countries find themselves paying from their local currencies against foreign currencies, which deteriorates the economic situation even more.

Following the abovementioned discussion on this issue, this study intends to investigate the effect of the international currency crisis on the Jordanian BoP. It is anticipated that the results of this study will demonstrate that the fluctuation of ERs of some currencies will have a positive effect on the BOP of Jordan, while others will have a negative impact. This observation is reflected in the short-run relationship.

The structure of this study is arranged into five sections. Section One presents the introduction and background to the study, followed by Section Two, which provides the review of literature relevant to this topic and hypotheses. Section Three presents and outlines the methodology and approach employed, followed by Section Four, which discusses the analysis and results, and lastly, Section Five presents the main findings of the study, including limitations, implications and recommendations.

\section{Literature Review}

Many studies have investigated the issue of ER fluctuations. Some studies have concentrated on the consequence of ER movements at the enterprise level (e.g., Šimáková, 2017; Verschoor Willem \& Muller, 2007), while others have merely focused on how the fluctuation in ERs influence different aspects of the economy (e.g., Trade balance, inflation, exports, etc.) in developed and developing countries. For instance, Vieira and MacDonald (2016) empirically examined the volatility of ERs on the size of exports in 106 countries between 2000 and 2011, focusing primarily on the effect related to the 2008 global financial crisis (GFC). The research found that the GFC had a positive impact, suggesting that the volume of exports was $0.14 \%$ higher following the GFC in comparison to the period between 2000 and 2007. However, the findings of this study are inconclusive, given they did not include oil export countries.

A separate study by Nasir and Simpson (2018) examined the consequences associated with the depreciation of the ER considering factors such as inflation on the trade balance of the UK between January 1989 and 2016 by employing a 'time-varying' structural vector auto-regression model. The findings revealed that depreciation had a major impact on inflation along with the balance of trade in the UK. Moreover, indicating that depreciation is useful towards improving the external balance along with directing inflation towards its statutory/legislative target. The research also found that with respect to 'inflation targeting,' substantial evidence was observed regarding a 'pass-through.' Similarly, Ebiringa and Anyaogu (2014) explored the correlations between inflation, INTs, and ER movements in Nigeria between 1971 and 2010 by applying an auto-regressive dispersed lag model in co-integrating analyses. Here the researchers revealed that a positive association was evident between the consumer price index (CPI) and the ER, although the interest rate (INT) was observed to affect the ER unfavorably and immaterially. In addition, the researchers recommended that given the association of inflation, INTs, and ERs in Nigeria, any policy that centers around one variable is insufficient. As such, in creating and sustaining a manageable ER system, inflation targeting is inappropriate. Also, merely focusing on ERs would be unsuitable. Another study by Kashif, Thiyagarajan, and Sridharan (2017) employed quarterly data representing the period between 1985_Q1 and 2014_Q4 by applying autoregressive distributed lag (ARDL) in assessing the impact associated with economic development and actual ERs on international reserves in Algeria by assessing the dynamics in the short-run and long-run. The research established evidence of a long-run association between international reserves, ERs, and economic development. Moreover, economic growth had a positive impact on international reserves, whereas actual ERs depicted an adverse impact.

Another series of studies, however, was found to be closer to the present study, in which they focused on the currency crisis and its association with the BoP in developing and developed countries. For instance, Hutchison and 
Noy (2002) investigated the outcome and its impact on extreme currency crises in emerging markets. Employing a panel data set covering the period between 1975 and 1997 and in 24 emerging-market economies, the researchers found that currency and the BoP crises, even following regulating for other facets, reduced the outcome by around $5-8 \%$ over a 24 to 36-month period. Moreover, the researchers contended that this negative effect was between 2-4 times higher compared to the average outcome loss within a developing economy. Similarly, Kandil (2009) explored the impact of ER variations on the major aspects associated with the BoP using a sample of developing and industrialized countries between 1971 and 2000. Here, the research applied a rational-expectation model agent towards engaging in the course of establishing projections regarding the ER, which was founded upon their observations of basic macroeconomics. Here the researchers considered that the effective ER would possibly worsen the balance of trade (through rising imports and declining exports) and that actual depreciation would perhaps improve it. Moreover, in the short run (i.e., 12 months according to data frequency), the flexibility of exports and imports would regulate the impact of ER variations on the balance of trade. In this situation, the answer with respect to export and ER changes would be reliant on the flexibility of foreign demand regarding ER changes.

Other researchers investigating the impact of the currency crisis on BoP focused on single countries, such as Ebaidalla (2014), who measured the impact of ER variations regarding Sudan's BoP employing data extracted from the Bank of Sudan for the period between 1970 and 2013. The results from the study revealed that the variables were integrated in the long run, indicating that the ER had a major influence from the standpoint of the BoP, while the unit change in the ER in generating 5.35 units decreased relative to the BoP. The study also presented recommendations towards the achievement of growth in the market-segment to improve exports and creating employment, in addition to regulating inflation to reduce poverty and reducing imports of non-productive goods. In another study, Batool et al. (2015) determined the BoP in Pakistan using data for the period between 1972 and 2013. Here the findings from the study revealed that a steady long-run association prevailed regarding the $\mathrm{BoP}$ and its causes. Moreover, the study suggested that the actual ER inversely affects the BoP, not merely in the long-run but also in the short-run. The results also indicate that INTs inversely influence the BoP in the long-run, and favorably influences the BoP in the short-run. Notwithstanding, the financial or economic balance also influences the BoP adversely in the short-run and long-run simultaneously. In Nigeria, Iyoboyi and Muftau (2014) investigated this relationship for the period between 1961 and 2012 in which the examination was founded on a multivariate vector error correction framework. Here, the researchers discovered a long-run equilibrium association between the BoP, ER, and other related variables. Here, the observed results positively favored bidirectional causality among the $\mathrm{BoP}$ and other variables used in the study.

Other studies have adopted alternate variables besides the ER, namely the INT and the inflation rate (IR), to examine the impact on the BoP. For instance, Shafi, Hua, Idrees, and Nazeer (2015) investigated the variation associated with three rates that were significant for any economy on BoP for the period between 1980 and 2008, specifically in Pakistan and India (i.e., foreign ER, INT, and IR). They found that the foreign ER and the IR had a favorable effect, whereas the INT had an adverse result on BOP in both countries. In a separate study by Ibarra and Blecker (2015), they examined the structural model of the BoP with disaggregated imports and exports and a reduction in the form model representing the balance of trade in the Mexican economy. The study employed a sample size representing 111 nations for the period between 1975 and 2012. The results indicated that a BOP restraint could constitute a post-liberalization slowdown concerning the development of Mexico as a nation during specific sub-periods. Further, the impact afforded by actual changes in ERs on the balance of trade lessened, probably resulting from the increased mixing of export industries on global supply chains.

In the context of Jordan, limited studies examined the issue of ER fluctuations. Al-Assaf, Al-Tarawneh, and Alawin (2013), in their research, created an advance warning system to clarify any probable currency crisis in Jordan by identifying several principal indicators that could assist in the comprehension of such a crisis. Here, they constructed a 'market pressure' index (MP) employing it in a multinomial legit model, utilizing monthly data between January 1976 and December 2010. The researchers discovered that aside from the index contained within the model, the real interest rates (RER), money supply-reserves ratio (M2R), the growth rate of domestic credit ( $\triangle \mathrm{DC})$ and Central Bank foreign assets to the liabilities ratio (AL), played a major part towards explaining the currency crisis. The study also revealed robust evidence in that the money supply to M2R and $\triangle \mathrm{DC}$ played a major part in the case whereby the borders or limit of the threshold become much broader (the number of estimated crises declines), and the approximated coefficients become increasingly irrelevant giving improper signs.

In another study by Sweidan (2013) the researcher attempted to explore the upshot of the movement in ERs on exports and imports in Jordan between 1976 and 2009, by testing Jordan's worker remittances in creating an effect, comparable to "the Dutch disease effect," on the competitiveness of exports in calculating the Marshall-Lerner condition to examine the stability of the foreign exchange market. Here, the researcher applied the 'bounds' testing 
method towards co-integration and the error correction framework model. The findings from the study found that Jordan's competitiveness displayed a downward or deteriorating pattern as the effect of Jordan's ER on exports and imports was only relative in the short run. Furthermore, Jordan's worker remittances had an effect like "the Dutch disease effect" through increases in the cost of living, thereby decreasing the competitiveness of the export industry. In addition, the Marshall-Lerner condition was less than one (1) indicating that the foreign exchange market would become unbalanced if the ER policy regarding devaluation was introduced into the market.

Given limited research presently available that explores the relationship between the international currency crisis and the BoP in the context of Jordan, this has motivated the authors in conducting this study. To the best of the author's knowledge, it is believed that this is the first study of its kind to examine the impact of the international currency crisis on the BoP in Jordan. The research constitutes an 18-year period (based on each quarter), which is considered appropriate in the context of this study.

\section{Data and Methodology}

\subsection{Data}

The aim and objective of this study were to examine the effect of the international currency crisis on the BoP of Jordan, as mentioned in the preceding section. Data were collected from the yearly reports issued by the Central Bank of Jordan, representing each quarter for the period between 2000 and 2017 for all currencies. The sampled currencies for the current study included Japanese Yen, US Dollar, European Euro, China Renminbi and UK Pound), and were selected according to the volume of trade between these countries and Jordan and because they are considered the most influential currencies in the global economy.

Three groups of variables were used in this study: control variables, independent variables, and dependent variables. The dependent variables represented the BoP, commonly referred to as the balance of international payments, which spells out and encapsulates all transactions within a country relating to government institutions and businesses external to the country, government institutions along with persons or employees, and the country's businesses and persons. The international currencies represented the independent variables in this study, namely, the Japanese Yen, US Dollar, Euro Member Countries, China Renminbi, and UK Pound). The last group, the control variables, consisted of Money Supply, Interest Rate, and Real Gross Domestic Product.

The first variable, Money Supply is described as the amount of currency that people and banking departments of SBP hold, deposits with SBP, net foreign assets of SBP, and scheduled bank demand deposits, etc., which are incorporated with respect to the meaning of money supply as mentioned by (Batool et al., 2015). The second variable is the interest rate $(\mathrm{R})$, which is the sum charged represented as a percentage to the primary amount, by a lender (the creditor) to a borrower (the debtor) utilized as assets. Rs are usually reported annually, as the annual percentage rate (APR). The last control variable is Real gross domestic product (GDP) which can be described as a measure of adjusted-inflation that mirrors the value of all services and goods produced by an economy in a specified year, stated in base-year prices, but commonly denoted as the "constant-price," "inflation-corrected" GDP or "constant dollar GDP." Dissimilar to nominal GDP, real GDP accounts for the differences in price levels and offers a precise representation of economic growth (Konchitchki \& Patatoukas, 2014).

\subsection{Model Specification}

In achieving the aim and objectives of this research, the following model was employed, created by (Eiteman et al., 2007) to calculate the BoP for Jordan:

$$
\mathrm{BOP}=(\mathrm{X}-\mathrm{M})+(\mathrm{CI}-\mathrm{CO})+(\mathrm{FI}-\mathrm{FO})+\mathrm{FXB}
$$

Where; BOP: Balance of Payment. X: Exports of goods and services. M: Imports of goods and services. CI: Cash Inflows. CO: Cash Outflows. FI: Financial Inflows. FO: Financial Outflows. FXB: official monetary reserves.

In addition, the following general model was used to investigate the effect of the international currency crisis on Jordan's BoP.

$$
\mathrm{BoP}_{\mathrm{t}}=f\left(M_{\mathrm{t}}, U S D / J O D_{\mathrm{t}}, J P Y / J O D_{\mathrm{t}}, E U R / J O D_{\mathrm{t}}, R A M / J O D_{\mathrm{t}}, G B P / J O D_{\mathrm{t}}, R_{\mathrm{t}}, M_{\mathrm{t}}, G D P_{\mathrm{t}}\right)
$$

Where:

BoP: Balance of Payments.

M: Money Supply

USD/ JOD: United States/ Jordan Dinar Exchange Rate 
JPY/ JOD: Japanese Yen/ Jordan Dinar Exchange Rate

EUR/ JOD: Euro Member Countries/ Jordan Dinar Exchange Rate

RAM/ JOD: China Renminbi/ Jordan Dinar Exchange Rate

GBP/ JOD: United Kingdom Pound/ Jordan Dinar Exchange Rate

R: Interest Rate

M: Money Supply

\section{GDP: Real Gross Domestic Product}

Estimation of the model relies on the Autoregressive Distributed Lag (ARDL) technique by Pesaran and Shin (1998) and Pesaran, Shin, and Smith (2001) in which this technique applies the model irrespective of the statistical properties of the variables. The ARDL technique is often referred to as ARDL bounds testing and has many benefits makings it a preferable approach used by many researchers compared to employing other methods to estimate the long-run co-integration relations. The primary benefits of this model relate to the model as a single equation, which easily interpreted. In line with the approach of Pesaran and Shin (1998) and Pesaran et al. (2001), a generalized ARDL (p, q) model can be represented as:

$$
\begin{gathered}
y_{t}=\alpha_{0}+\alpha_{1} t+\sum_{i=1}^{p} \varphi_{i} y_{t-1}+\dot{\beta} x_{t}+\sum_{i=1}^{q-1} \dot{\beta}_{l}^{*} \Delta x_{t-1}+\mu_{t} \\
\Delta x_{t}=P_{1} \Delta x_{t-1}+P_{2} \Delta x_{t-2}+\cdots+P_{s} \Delta x_{t-s}+\varepsilon_{t}
\end{gathered}
$$

Where $y_{\mathrm{t}}$ is the dependent variable, $x_{\mathrm{t}}$ is a vector of explanatory variables and are the uncorrelated error terms with zero mean and constant variance. The model is reworked as:

$$
\varphi(L) y_{t}=\alpha_{0}+\alpha_{1} t+\sum_{i=0}^{k} \dot{\beta}_{t}(L) x_{t}+\mu_{t}
$$

Where

$$
\begin{aligned}
\varphi(L)=1-\varphi_{1}(L) & -\varphi_{2}(L)^{2} \ldots-\varphi_{p} L^{p}, \hat{\beta}(L) \\
= & \beta_{0}-\beta_{1} L-\beta_{2} L^{2} \ldots-\beta_{q} L^{q}, \text { and } L \text { is the lag operator. For Simplicity define: } \delta \\
= & \frac{\alpha_{1}}{1-\varphi} \text { and } \theta=\frac{\beta}{1-\varphi}
\end{aligned}
$$

As such, $y_{\mathrm{t}}$ can be expressed as:

$$
y_{t}=\mu+\delta t+\sum_{i=0}^{k} \theta_{t}(L) x_{t}+v_{t}
$$

Where $\mu=\frac{\alpha_{0}}{1-\varphi}-\left(\frac{\varphi}{1-\varphi}\right) \delta$, and $v_{t}$ represent the error term.

Thus, the long-run co-integration vector is then represented as:

$$
y_{t}-\hat{\theta}_{0}-\hat{\theta}_{1} x_{1 t}-\hat{\theta}_{2} x_{2 t}-\cdots-\hat{\theta}_{k} x_{k t}=v_{t}
$$

Using the lag and first differences of $\mathrm{y}$ and $\mathrm{x}$, the following is obtained:

$$
\Delta y_{t}=\beta_{0}+\sum_{i=1}^{r} \beta_{i} y_{t-1}+\sum_{j=1}^{k} \sum_{i=1}^{r} \delta_{j i} x_{j, t-i}+\sum_{i=1}^{r} \pi_{i} \Delta y_{t-i}+\sum_{j=1}^{k} \sum_{i=1}^{r} \Upsilon_{j i} \Delta x_{j, t-i}+\mu_{t}
$$

Where $\beta_{0}$ is a deterministic variable, $j$ is the number of explanatory variables, $r$ is the number of lags chosen founded on the information criteria, and $\mu_{t}$ is the white noise disturbance. Implementing this method consists of several stages. First, testing for the presence of a co-integration relation among the $y_{t}$ and $x_{j t}$ variables employing the bounds 
test and F-test. The null hypothesis of the test postulates that there is no co-integration relation amongst the variables, which can be undertaken as a joint significance test on the lagged level variable's coefficients, as shown below:

$$
\mathrm{H} 0: \beta_{0}=\delta_{j i}=0 \quad \forall i=1,2, \ldots r \text { and } j=1,2, \ldots k
$$

The F test delivers several (2) sets of critical values and bounds: one is founded on the supposition in which all variables in the ARDL model are $I(1)$, while the second set presumes that all variables are $I(0)$. Here, if the computed $\mathrm{F}$ value is greater compared to the upper critical bound, as such, the null hypothesis is rejected. Accordingly, a co-integration relation among the variables prevails. However, if the test statistic is smaller than the lower critical bound, as such, the null hypothesis cannot be rejected. Additionally, if the computed F-test is amongst the bounds, accordingly, the test cannot offer a definite inference. During the second stage, if the long-run relation prevails, as such, the long-run and short-run coefficients of Equation (9) are able to be estimated. The investment function is shown below:

$$
\Delta B O P_{t}=\beta_{0}+\sum_{i=1}^{p} \beta_{i} B O P_{t-1}+\sum_{i=0}^{p} \sum_{j=1}^{k} \gamma_{j i} \Delta E X R_{j, t-i}+\sum_{j=1}^{k} \delta_{j} \operatorname{EXR}_{j, t-1}+\varepsilon_{t}
$$

Where $\Delta$ stand for the first difference, and $p=1,2$ represent the determined number of lags by the information criteria, $k$ denotes the number of independent variables, and $E X R_{t}$ represents a vector of the explanatory variables.

\section{Empirical Results}

\subsection{Unit Root Test}

Prior to conducting the ARDL bounds test, there was a requirement to test for the stationarity status of the variables in determining their integration arrangement or order in order to confirm that the variables were not stationary in order 2 to evade false results. The presence of $I(2)$ variables via the calculated F-statistics given by Pesaran et al. (2001) would not, in this case, be valid since the bounds test presumes that the variables are $I(0)$ or $I(1)$. Accordingly, the execution of the unit root tests in the ARDL technique was necessitated in order to confirm that none of the variables were integrated of order 2 or beyond. As such, the tests were executed, having intercept and linear trends. Table 1 displays the results of the Augmented Dickey-Fuller (ADF) and Phillips-Perron (PP) tests in levels, including the initial variance for all variables.

\begin{tabular}{|c|c|c|c|c|c|}
\hline \multirow[t]{2}{*}{ Variables } & \multirow{2}{*}{$\begin{array}{c}\text { Order of } \\
\text { integration }\end{array}$} & \multicolumn{2}{|c|}{ T-Statistics ADF } & \multicolumn{2}{|c|}{ T-Statistics PP } \\
\hline & & Level & $1^{\text {st }}$ Difference & Level & $1^{\text {st }}$ Difference \\
\hline $\mathrm{BOP}$ & $\mathrm{I}(0)$ & $-4.77062 * *$ & & $-6.13625 * *$ & \\
\hline USD/ JOD & $\mathrm{I}(0)$ & $-6.46358 * *$ & & $-6.46358 * *$ & \\
\hline JPY/ JOD & $\mathrm{I}(\mathrm{I})$ & -0.34541 & $-6.96268 * *$ & -0.41020 & $-8.44624 * *$ \\
\hline EUR/ JOD & $\mathrm{I}(\mathrm{I})$ & -1.96086 & $-5.92030 * *$ & 0.19582 & $-8.27491 * *$ \\
\hline RAM/ JOD & $\mathrm{I}(\mathrm{I})$ & 1.07340 & $-2.53691 *$ & 1.41865 & $-5.66757 * *$ \\
\hline GBP/ JOD & $\mathrm{I}(\mathrm{I})$ & -0.39486 & $-4.61109^{* *}$ & -0.52611 & $-6.65888^{* * *}$ \\
\hline M & $\mathrm{I}(\mathrm{I})$ & -3.33831 & $-3.36288^{*}$ & -2.97152 & $-8.31045^{* *}$ \\
\hline GBD & $\mathrm{I}(\mathrm{I})$ & -0.74237 & $-6.19086 * *$ & -1.14936 & $-8.21917 * *$ \\
\hline $\mathrm{R}$ & $\mathrm{I}(0)$ & $-3.11329 * *$ & & $-3.12544 * *$ & \\
\hline GDP & $\mathrm{I}(\mathrm{I})$ & -2.35929 & $-2.61910 *$ & -2.83880 & $-6.10474 * *$ \\
\hline
\end{tabular}

Table 1. Results of unit root tests

*Significant at $1 \%$ and $* *$ significant at $5 \%$.

The results of the ADF and PP tests for all variables are displayed in Table 1, indicating that all variables were integrated, regardless of the initial difference or level, $I(1)$ or $I(0)$. As such, this suggests that the ARDL model can be employed in this study. The computed F-statistics of the bounds test can be seen in Table 2 below.

\subsection{Co-integration Testing Using the ARDL Bounds Test}

To observe the prevalence of a co-integration relation amongst the variables, the bounds test suggested by Pesaran et al. (2001) was used founded upon testing the null hypothesis of no co-integration relation amongst the variables. Table 2 displays the results from the bounds test. 
Table 2. Results of Bounds Test

\begin{tabular}{lcccc}
\hline F-Statistics & Significant level & Lower Bound I(0) & Upper Bound I(1) & Remark \\
\hline 4.338204 & $1 \%$ & 2.62 & 3.77 & Co-integrated \\
& $2.5 \%$ & 2.33 & 3.42 & 3.15 \\
& $5 \%$ & 2.11 & 2.85 & \\
\hline
\end{tabular}

The computed F-statistics (4.338) that exceeds the upper critical bound at the $1 \%$ significance level are shown in Table 2. As such, the null hypothesis of no co-integration is rejected given the long-run relation exists in the model.

\subsection{Estimation Results}

Table 3 below displays the result founded on the long-run ARDL approach. Here, BoP is employed as the dependent variable, and the independent variables are the ERs of the currencies that include the Japanese Yen, US Dollar, European Euro, China Renminbi, and UK Pound. These were selected not only according to the volume of trade between these countries and Jordan but also because they are considered as the most influential currencies in the global economy. There are three control variables, as mentioned earlier, Growth Budget Deficit, Interest Rate, Money Supply, and Real Gross Domestic Product. The outcomes from the descriptive statistics suggest that R-square designates a $67 \%$ difference in the BoP, which can be explained by the independent variables of the study. Akaike info criterion (AIC) and Schwarz criterion (SIC) values show that the model is suitable for the intended analysis. Durbin Watson's value is 1.94 , therefore, indicating that there is no problem of autocorrelation in the data. The $\mathrm{F}$ statistics values show that the model is suitable (Gujarati, 2007).

Table 3. Results of the long run ARDL model

\begin{tabular}{|c|c|c|c|c|}
\hline Variables & Coefficient & St. Error & t-statistics & Prob. \\
\hline RAM/JOD & -12270.315 & 10513.45 & -1.1671 & 0.2496 \\
\hline EUR/JOD & 2615.442 & 779.898 & 3.3535 & 0.0017 \\
\hline JPY/JOD & -165118.540 & 65820.420 & -2.5086 & 0.0160 \\
\hline GBP/JOD & -520.551 & 651.352 & -0.7991 & 0.4286 \\
\hline USD/JOD & -80078.793 & 116606.383 & -0.6867 & 0.4959 \\
\hline M & -3784.771 & 2132.670 & -1.7746 & 0.0830 \\
\hline $\mathrm{R}$ & -173.611 & 34.365 & -5.0519 & 0.0000 \\
\hline GDP & 2138.778 & 2664.560 & 0.8026 & 0.4266 \\
\hline \multicolumn{2}{|c|}{ R-squared } & 0.6775 & Akaike info criterion & 15.5538 \\
\hline \multicolumn{2}{|c|}{ Adjusted R-Squared } & 0.5057 & Schwarz criterion & 16.1735 \\
\hline \multicolumn{2}{|c|}{ F-statistic } & 3.9283 & Durbin-Watson stat & 1.9446 \\
\hline \multicolumn{2}{|c|}{ Prop (F-statistic) } & 0.0000 & & \\
\hline
\end{tabular}

The outcomes relating to the long-run ARDL model suggest that the ER variation in Chinese Renminbi RAM/JOD had a negative relation but was not significant on the BoP of Jordan, while the P-value was greater than the significant level of $10 \%$. Although the trade between Jordan and China is at high level, the fluctuation in the ER does not lead to an effect on the BoP since such trade is mostly undertaken by a third currency which is the US dollar, and the Chinese government is always keen to hold their currency price fixed against the harder currencies like the US Dollar, which leads to no significant consequence on the BoP of countries that import from these countries (Angeloni et al., 2011).

Regarding the ER variance or fluctuation in the EUR/JOD, the result indicated that it had a positive and significant outcome on the BoP in the long-run relation at a significant level of $1 \%$, meaning that a rise of $1 \%$ in the ER will lead to an increase in the BoP of 2615 JD. As such, the Jordanian government maintains a floating ER to the Euro. For the third currency JPY/JOD, the result showed that the fluctuation in the ER had an adverse and major impact effect on the BoP in Jordan at a significant level of 5\%, where a rise in the ER of Japanese Yen with the Jordanian Dinar of $1 \%$ could lead towards a significant decrease in the BoP. 
The above results are aligned with the relative form of the Purchasing Power Parity Theory (PPP) or "Law of one price" which affirms that beginning from a foundation of an equilibrium or balanced exchange rate among two currencies, the forward projecting view of the exchange rate among the two currencies is determined by the relative movements or shift in the price level of the two countries. The hypothesis in this respect flourishes in an economy with floating ERs (Gatawa, Elijah, and Mohammed, 2018) such as Jordan. In other words, the floating ER between these currencies and the Jordanian dinar is set to the price level in the home countries of these currencies and the price levels in Jordan. Regarding the Euro, it appears that the price level in Jordan and that of home countries of the Euro currency imposes a similar direction, in which the increase in the ER could result in a positive effect on the BoP of Jordan. For the final two ERs, the GBP/JOD and USD/JOD, the results showed an adverse effect, but an insignificant effect on the BoP in Jordan. This could be because Jordan uses a fixed ER to the Dollar, which does not constitute any difference in the BoP where the ER is increases or decreases. This result is consistent with that of (Gatawa, Elijah, \& Mohammed, 2018). For the control variables, the money supply and INT variables were found to have a negative and significant effect on the BOP, while the GDP variable had no effect.

Table 4. Results of short run ARDL model

\begin{tabular}{lcccc}
\hline Variables & Coefficient & St. Error & t-statistics & Prob. \\
\hline BOP $_{(t-1)}$ & 0.89411 & 0.238074 & 3.75563 & 0.0005 \\
RAM/JOD $_{t}$ & -14167.95 & 18698.09 & -0.7577 & 0.4528 \\
EUR/JOD $_{(t-1)}$ & 4361.497 & 1510.528 & 2.8874 & 0.0061 \\
JPY/JOD $_{t}$ & -270054.7 & 118191.7 & -2.2848 & 0.0273 \\
GBP/JOD $_{t}$ & -1221.119 & 1177.375 & -1.0371 & 0.3055 \\
USD/JOD $_{(t-4)}$ & -175498.8 & 83377.35 & -2.1048 & 0.0412 \\
$\mathrm{M}_{t}$ & -5304.8 & 3676.091 & -1.4430 & 0.1563 \\
$\mathrm{R}_{t}$ & -503.52 & 164.989 & -3.0518 & 0.0039 \\
$\mathrm{GDP}_{(t-2)}$ & -7082.078 & 3554.366 & -1.9925 & 0.0527 \\
\hline
\end{tabular}

The result of the short-run ARDL method for the suggested model is shown in Table 4. The lag in the ER for Euro currency has a positive effect on the BOP, while the lag in the ER for JPY/JOD and USD/JOD currencies had a negative impact effect on the BOP. This suggests that in comparison to the long-run results, the fluctuation in ERs for these currencies affect the BOP, but only in the short-run relationship.

Table 5. Serial Correlation and Heteroskedasticity Test

\begin{tabular}{lcll}
\hline Breusch-Godfrey Serial Correlation LM Test & & \\
\hline F-statistic & 1.400765 & Prob. F(2,4) & 0.2580 \\
Obs*R-squared & 4.285297 & Prob. Chi Square (2) & 0.1173 \\
\hline Heteroskedasticity Test: Breusch-Pagan-Godfrey & & \\
\hline F-statistic & 0.997419 & Prob. F (23,4) & 0.4880 \\
Obs*R-squared & 23.30919 & Prob. Chi Square (23) & 0.4428 \\
\hline
\end{tabular}

Table 5 displays the result from the Breusch-Godfrey and Breusch Pagan Godfrey tests for serial correlation and Heteroskedasticity, respectively. The result from the Breusch Godfrey test suggests that no problems exist regarding serial correlation in the data since the P-value of the F-statistics exceeds 0.05. The Breusch Pagan Godfrey result further shows that the P-value exceeds 0.05 , therefore, indicating that no Heteroskedasticity problems are evident in the data.

\section{Conclusions and Recommendations}

The effect of fluctuations in ERs related to several international currencies on the BoP position in Jordan between Q1-2000 and Q4-2017 was examined in this study. The empirical findings and results from the ARDL bound testing method showed that a long-run relation prevailed amongst the ERs and the BoP in Jordan. Likewise, the elasticity of the ER coefficient for the EUR/JOD in the BoP model was shown to be both positive and statistically significant at a 1 percent level. Therefore, the BoP standpoint in Jordan countered favorably to the country's ER policies. 
However, in contrast, the ER coefficient for the JPY/JOD, in the BoP model was shown to be negative and significant in the BoP of Jordan at the significant level of 5\%, in which a rise in the ER of the Japanese Yen with the Jordanian Dinar of $1 \%$ could result in a significant decrease in the BoP. Regarding the fluctuation or variance in ERs in the remaining currencies, the results indicated they had a negative relation, though not significant on the BoP of Jordan, in which the P-value was found to be at a more significant level of $10 \%$. Additionally, the dynamic error correction mechanism showed that the ability to adjust quickly to the long-run equilibrium standpoint period previously to the present is moderate. Here, the ECM coefficient was properly depicted, having a negative sign.

The policy implications regarding the estimation outcomes are quite evident since devaluation /depreciation improves the BoP, and that the Marshall-Lerner (ML) condition prevails in the Jordanian economy. Accordingly, management of the ER in Jordan must be viewed from the long-run instead of concentrating on the short-run impact. Therefore, to lessen the substantive adverse impact afforded by these currencies on the BoP in Jordan, over-reliance on the promotion of domestic export products and imported goods must be discouraged. Although the achievement of this outcome will only be achieved if the Jordanian economy is expanded, and business innovation and development are promoted and supported by fiscal disciplines. Accordingly, the study recommends that the monetary authority (the Central Bank of Jordan) should adopt measures that limit the negative effect of international currency crises, through issuing instructions, in addition to supervising financial institutions carefully.

\section{References}

Al-Assaf, G., Al-Tarawneh, A., \& Alawin, M. (2013). Determinants of currency crisis in Jordan a multinomial logic model. European Scientific Journal, 9(34), 354-359. Retrieved from https://pdfs.semanticscholar.org/b363/8b025f021da70d28d442076a9b87eba2c663.pdf

Alawin, M., \& Oqaily, M. (2017). Current Account Balance, Inflation, Industry and Sustainable Development in Jordan. Revista Galega de Economia, 26(3), 45-56. Retrieved from https://www.redalyc.org/pdf/391/39153623004.pdf

Al-Rdaydeh, M., Almansour, A. Y., \& Al-Omari, M. A. (2018). Moderating effect of competitive strategies on the relation between financial leverage and firm performance: Evidence from Jordan. Business and Economic Horizons, 14(3), 626-641. https://doi.org/10.15208/beh.2018.44

Angeloni, I., Bénassy-Quéré, A., Carton, B., Destais, C., Darvas, Z., Pisani-Ferry, J., \& Sapir, A. (2011). Global currencies for tomorrow: a European perspective. Bruegel Blueprint 13, 2 August 2011.

Batool, S. A., Memood, T., \& Jadoon, A. K. (2015). What determines balance of payments: A case of Pakistan. Sukkur IBA Journal of Management and Business, 2(1), 47-70. https://doi.org/10.30537/sijmb.v2i1.88

Ebaidalla, E. (2014). Impact of exchange rate volatility on macroeconomic performance in Sudan. Journal of Development and Economic Policies, 16(1), 73-105.

Ebiringa, O. T., \& Anyaogu, N. (2014). Exchange rate, inflation and interest rates relationships: An autoregressive distributed lag analysis. Journal of Economics and Development Studies, 2(2), 263-279. Retrieved from http://jedsnet.com/journals/jeds/Vol_2_No_2_June_2014/15.pdf

Gatawa, N., Elijah, S., \& Mohammed, U. (2018). An empirical analysis of the impact of floating exchange rate on balance of payment in Nigeria (1986-2016). Turkish Economic Review, 5(3), 285-307. https://doi.org/10.1453/ter.v5i3.1751

Gouvea, R. R., \& Lima, G. T. (2013). Balance-of-payments-constrained growth in a multisectoral framework. Journal of Economic Studies. https://doi.org/10.1108/01443581311283691

Gujarati, D. N. (2007). Basic econometrics (3rd ed.). McGraw-Hill, New York.

Hamouri, B., Al-Rdaydeh, M., \& Ghazalat, A. (2018). Effect of financial leverage on firm growth: Empirical evidence from listed firms in Amman stock exchange. Investment Management and Financial Innovations, 15(2),154-164. https://doi.org/10.21511/imfi.15(2).2018.14

Hutchison, M. M., \& Noy, I. (2002). Output costs of currency and balance of payments crises in emerging markets. Comparative Economic Studies, 44(2-3), 27-44. https://doi.org/10.1057/ces.2002.8

Ibarra, C. A., \& Blecker, R. A. (2015). Structural change, the real exchange rate and the balance of payments in Mexico, 1960-2012. Cambridge Journal of Economics, 40(2), 507-539. https://doi.org/10.1093/cje/beu079

Iyoboyi, M., \& Muftau, O. (2014). Impact of exchange rate depreciation on the balance of payments: Empirical evidence from Nigeria. Cogent Economics \& Finance, 2(1), 923323. 
https://doi.org/10.1080/23322039.2014.923323

Kalayci, S. (2019). Comparing the Balance of Payments of Northern and Southern European Countries in Terms of Heckscher Ohlin Theory. Economics and Politics. Retrieved from https://www.researchgate.net/profile/Ersin_Kiral/publication/332188128_Economics_and_Politics/links/5cbd6 d894585156cd7a8d15f/Economics-and-Politics.pdf\#page $=22$

Kandil, M. (2009). Exchange rate fluctuations and the balance of payments: channels of interaction in developing and developed countries. Journal of Economic Integration, 151-174. Retrieved from https://www.jstor.org/stable/23000947

Kandil, M., \& Greene, J. (2002). The impact of cyclical factors on the US balance of payments (Vol. 2). International Monetary Fund.

Kashif, M., Thiyagarajan, S., \& Sridharan, P. (2017). Dynamics of Algeria's international reserves. African Journal of Economic and Management Studies, 8(4), 410-419. https://doi.org/10.1108/AJEMS-11-2016-0179

Konchitchki, Y., \& Patatoukas, P. N. (2014). Accounting earnings and gross domestic product. Journal of Accounting and Economics, 57(1), 76-88. https://doi.org/10.1016/j.jacceco.2013.10.001

Nasir, M., \& Simpson, J. (2018). Brexit associated sharp depreciation and implications for UK's inflation and balance of payments. Journal of Economic Studies, 45(2), 231-246. https://doi.org/10.1108/JES-02-2017-0051

Pesaran, M. H., \& Shin, Y. (1998). An autoregressive distributed-lag modelling approach to cointegration analysis. https://doi.org/10.1017/CCOL0521633230.011

Pesaran, M. H., Shin, Y., \& Smith, R. J. (2001). Bounds testing approaches to the analysis of level relationships. Journal of Applied Econometrics, 16(3), 289-326. https://doi.org/10.1002/jae.616

Ribeiro, R. S., McCombie, J. S., \& Lima, G. T. (2016). Exchange rate, income distribution and technical change in a balance-of-payments constrained growth model. Review of Political Economy, 28(4), 545-565. https://doi.org/10.1080/09538259.2016.1205819

Ribeiro, R. S. M. (2019). Balance-of-Payments Constrained Growth Model: The Brazilian Case over the Period 1980-2011. International Integration of the Brazilian Economy (pp. 265-288). Springer.

Shafi, K., Hua, L., Idrees, Z., \& Nazeer, A. (2015). Impact of exchange rate, inflation rate and interest rate on balance of payment: A study from India and Pakistan. American Journal of Business, Economics and $\begin{array}{llll}\text { Management, } & 3(1), & \text { Retrieved } & \text { from }\end{array}$ http://www.openscienceonline.com/journal/archive2?journalId=709\&paperId=1418

Šimáková, J. (2017). The Impact of Exchange Rate Movements on Firm Value in Visegrad Countries. Acta Universitatis Agriculturae et Silviculturae Mendelianae Brunensis, 65(6), 2105-2111. https://doi.org/10.11118/actaun201765062105

Sweidan, O. D. (2013). The Effect of Exchange Rate on Exports and Imports: The Case of Jordan. The International Trade Journal, 27(2), 156-172. https://doi.org/10.1080/08853908.2013.738515

Verschoor Willem, F. C., \& Muller, A. (2007). The Asian crisis exchange risk exposure of US multinationals. Managerial Finance, 33(9), 710-740. https://doi.org/10.1108/03074350710776253

Vieira, F. V., \& MacDonald, R. (2016). Exchange rate volatility and exports: a panel data analysis. Journal of Economic Studies. https://doi.org/10.1108/JES-05-2014-0083

\section{Copyrights}

Copyright for this article is retained by the author(s), with first publication rights granted to the journal.

This is an open-access article distributed under the terms and conditions of the Creative Commons Attribution license (http://creativecommons.org/licenses/by/4.0/). 